\title{
細胞周期を標的とした抗がん薬開発
}

\author{
平井 洋, 下村 俊泰, 駒谷 秀也, 小谷 秀仁
}

要約：正常な体細胞ががん化する為には, 細胞のいく つかの制御機構に異常が引き起こされることが必要と 考えられている(1).これらは, 細胞増殖のシグナル の異常, 細胞死制御の異常, DNAの修復機構の異常 などが含まれるが, その中でも, 細胞周期に変化を起 こすような細胞分裂制御機構の異常は細胞のがん化に おけるひとつの大切なホールマークとして知られている.

細胞分裂は 4 つの周期に分けられており, それらは $\mathrm{G} 1$ 期， $\mathrm{S}$ 期， G2 期， M 期で，それぞれ異なった夕ン パク質がその時期の制御に関わっている. 現在使用さ れている抗がん薬の多くは，この細胞周期の 1 つまた は，複数期に関わっているタンパク質の活性を阻害す るものであり, その臨床的な有用性は様々な研究によ って証明されている.

しかしながら, 現行の抗がん薬には様々な副作用も 知られており，また，多くの抗がん薬がその化合物が 天然物由来であることもあり, 阻害メカニズムに由来 した以上の副作用も存在している。 これらのことから， 患者さんからは副作用の少ない次世代の抗がん薬の創 製が強く望まれている。

以上のような理由から, 現在細胞分裂の制御に関係 したタンパク質の阻害薬が多くの研究者, 企業によっ て開発されている。このレビューでは, 特に, 現在そ の標的に対して薬が作られていない新規の細胞分裂抗 がん薬ターゲットに着目してその開発状況を報告する.

\section{Aurora キナーゼ阻害薬}

ヒトの Aurora キナーゼは, 3 種類のセリン・スレ オニンキナーゼ (Aurora-A, Aurora-B, Aurora-C) からなるタンパク質キナーゼファミリーである (2). Aurora キナーゼの発現は細胞周期の G2 期および $\mathrm{M}$
期に上昇し，種々の分子と相互作用しながら細胞分裂 の制御に重要な役割を果たしている。興味深いことに, タンパク質レベルの相同性が高いにも係わらずAurora-A と Aurora-B の細胞分裂期における局在および役 割は大きく異なっている. Aurora-A は主に中心体お よび紡錘糸に局在し G2 期から M 期への移行および $\mathrm{M}$ 期における双極紡錘体の形成を制御している。一方, Aurora-B は M 期中期までは染色体に局在するが染色 体の分離に伴って染色体から微小管上のセントラルス ピンドルさらにはミッドボディーと呼ばれる領域へと 局在を変化させる. 局在の変化と一致して, Aurora-B は M 期中期までは染色体と紡錘糸の結合を監視 するチェックポイントを制御するが, 後期以降は細胞 質分裂の制御を行う。Aurora-Cの役割に関しては不 明な点が多い.

Aurora-A およびAurora-B の発現は, 種々のがん 組織で周辺の正常組織に比べ艺進している (3).さらに, Aurora-A 遺伝子領域 (20q13.2) の増幅は種々のがん で報告されている. Aurora-Aの過剩発現は中心体の 増幅や染色体分配の異常を引き起こすことが知られて おり, NIH3T3 細胞や Rat-1 䋊維芽細胞に形質転換を 誘導するという報告がある。一方, Aurora-Bの遺伝 子増幅は報告されていないが, その過剩発現は頻繁に 観察されている. Aurora-Aの増幅・過剩発現や Aurora-B の過剩発現が予後不良と関連していることから, Aurora-AあるいはAurora-Bの阻害薬は優れた抗が ん薬になるのではないかと考えられている. 現在, さ まざまな Aurora キナーゼ阻害薬が臨床試験または前 臨床段階で開発されている. 以下に, 代表的な Auroraキナーゼ阻害薬について紹介する.

\section{(1) MK-0457}

MK-0457（VX-680）は，米国メルク社が開発中の

キーワード：抗がん薬, 細胞周期, 分子標的薬. 万有製薬(株) つくば研究所（テ300-2611 茨城県つくば市大久保 3 番地） E-mail: hidehito_kotani@merck.com 原稿受領日：2008 年 7 月 27 日, 依頼原稿 Title: Novel anti-cancer compounds targeting the cell cycle.

Author: Hiroshi Hirai, Toshiyasu Shimomura, Hideya Komatani, Hidehito Kotani 
Aurora キナーゼ阻害薬である. Aurora-A， -B，-Cに 対する Ki はそれぞれ $0.66 \mathrm{nM}, 18 \mathrm{nM}, 4.6 \mathrm{nM}$ である。 さらに, FLT3 や変異型 Bcr-Abl（T315I）に対する阻 害活性も有する。前臨床試験において MK-0457は, 種々のがん細胞に対して強い細胞増殖抑制効果を示し, ヌードマウス・ヌードラットを用いたゼノグラフトモ デルにおいても抗腫瘍効果を示した．ゼノグラフトに おいて Aurora-B の基質である Histone $\mathrm{H} 3$ のリン酸 化を阻害したことから， MK-0457 は Aurora-A と Aurora-Bをともに阻害していると考えられている(4). MK-0457 の臨床試験は IV 投与で行われている. 固形 がんを対象とした Phase I 臨床試験において, 好中球 減少症が用量制限毒性（DLT）として同定されている (5)。興味深いことに, Bcr-Abl T315I 変異を持つ慢性 骨髄性白血病（CML）または急性リンパ球性ノリン パ芽球性白血病 (ALL) 患者を対象としたPhase I/II 試験において MK-0457は治療効果を示した. MK-0457 の持つ Bcr-Ab1 T315I に対する阻害効果が, この治療効果に影響している可能性が示唆されている (6).

\section{(2) PHA- 739358}

PHA-739358 は Nerviano Medical Sciences 社が開発 中の Aurora キナーゼ阻害薬であり, その酵素阻害活 性 $\left(\mathrm{IC}_{50}\right)$ は Aurora-A，-B，-Cに対してそれぞれ 13 $\mathrm{nM}, 79 \mathrm{nM}, 61 \mathrm{nM}$ である.この化合物も FLT3 およ び Abl に対する阻害活性を示す. MK-0457 と同様に, 前臨床試験において Aurora キナーゼを阻害して抗腫 瘍効果を示した(7). 固形がんを対象としたPhase I 臨床試験が IV 投与により実施され, その用量制限毒 性（DLT）は好中球減少症であった(3).

\section{(3) AZD1152}

AZD1152 は，アストラゼネカ社が開発中のプロド ラッグで, 体内で活性型の AZD1152-HQPAに変換さ れる. AZD1152-HPQA は Aurora-B (Ki=0.36 nM) と Aurora-C $(\mathrm{Ki}=17 \mathrm{nM})$ に対して強い活性を示すが, Aurora-A（Ki=1369 nM）に対して選択性を持つ. 複 数のゼノグラフトモデルにおいて抗腫瘍効果を示し, また Histone H3 のリン酸化を阻害することが報告さ れている(8).AZD1152 は臨床試験において IV 投与 されており, 用量制限毒性（DLT）は好中球減少症で あった(9).

\section{(4) MLN8054 $\cdot$ MLN8237}

MLN8054 と MLN8237 は Millennium Pharmaceuticals 社が開発中の Aurora-A 阻害薬である. MLN8054 の Aurora-A，-B に対する䤉素阻害活性（ $\mathrm{IC}_{50}$ ) はそ れぞれ $4 \mathrm{nM}$ と $172 \mathrm{nM}$ である. 細胞内の Aurora-A
およびAurora-B の活性阻害効果はそれぞれ $34 \mathrm{nM}$ と $5.7 \mu \mathrm{M}$ であり, Aurora-A 選択的な阻害効果を示す可 能性が示唆されている。 ゼノグラフトモデルを用いた 試験において, MLN8054 はがん細胞の細胞周期の分 裂期での停止と Histone H3 のリン酸化の克進を抗腫 瘍効果が観察される投与量において誘導した。この結 果は MLN8054 がゼノグラフトモデルにおいて Aurora-A を選択的に阻害し抗腫瘍効果を示している可能 性を示唆する(10). MLN8054 は Phase I 臨床試験に おいて経口で投与された。その用量制限毒性（DLT） は他の Aurora キナーゼ阻害薬と異なり somnolence (傾眠作用) であり, 重篤な血球減少は報告されてい ない(11). MLN8237 は, 最近の米国癌学会で報告さ れた化合物でMLN8054 と非常に類似の構造を持つ (12). 現在, Phase I 臨床試験が進行中である.

以上のように, 性質の異なるいくつかの Aurora キ ナーゼ阻害薬が臨床試験において評価されている。 そ の有効性さらには Aurora キナーゼ間の選択性の影響 に関しては今後の臨床試験で明らかになっていくこと が期待される.

\section{PLK（polo like kinase）阻害薬}

PLK1 は細胞周期の M 期の進行を担うキナーゼと して知られており，Aurora キナーゼと並び M 期にお ける抗がん薬の標的として近年注目を集めている. PLK は真核生物で保存されたセリン・スレオニン・ キナーゼファミリーであり，ヒトに拈いては 4 種類の PLK, 即ち PLK1，2，3，4 の存在が知られている (13). これらファミリーの中で, PLK1 は最も詳細な機能 の解析が進んでいる分子であり, 細胞周期の $\mathrm{M}$ 期の 進行に损いて重要な役割を担っていることが明らかに なっている. PLK1 は中心体の成熟や, 紡錘体形成, 細胞質分裂などの $\mathrm{M}$ 期における複数のステップを調 節する(13) ことにより正常な $\mathrm{M}$ 期の進行を制御して

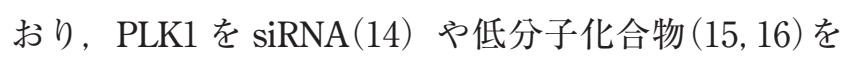
用いて阻害すると, 中心体や紡錘体形成の異常や細胞 周期に打ける $\mathrm{M}$ 期中期での停止が誘導される.

PLK1 が抗がん薬の標的の候補として考えられる理 由として, PLK1 が広範囲のがん種で過剩発現してい ることが数多く報告されているということが上げられ る(17)。また，いくつかのがん種においてはその発現 レベルと予後が相関していること(18-21), PLK1 の 過剩発現が実験的に細胞のがん化をもたらすこと(22) なども報告されておりがんの発生と進行のメカニズム との関連という意味で興味深い。さらに, PLK1 阻害 のがん細胞に対する効果を調べる目的で，これまでに 
様々な分子生物学的手法による実験が行われてきてお り，実際にPLK1 の阻害ががん細胞に対し強い抗腫瘍 効果をもたらすことが示唆されてきている．例えば siRNAを用いた実験では，PLK1 発現レベルの抑制に より様々ながん細胞に増殖抑制とアポトーシスが誘導 され(23)，またPLK1 に対する shRNAをヌードマウ スに投与することにより移植がんの増殖が強く抑制さ れることが示された $(24)$. 上記の結果は PLK1 阻害薬 の抗がん薬としての可能性を強く示唆するものである. 一方, PLK1 阻害に由来する毒性に関しては情報が少 ないが，PLK1 がM 期進行に不可欠であることを考 慮すると増殖正常細胞に対するある程度の影響は考え られる。ただし興味深いことに, 細胞レベルでの実験 ではある種のがん細胞は培養正常細胞と比較して PLK1 阻害に対してょり強い感受性を示すことが報告 されている $(14,25,26)$. 従って相対的に感受性の高い がんを狙うことによって，よりがん細胞選択的な効果 を期待することも可能かもしれない.

このような背景のもとに近年, PLK1 を主要なター ゲットとした抗がん薬の開発が行われてきているが, それらのうち多くのものは PLK1 キナーゼの ATP 結 合領域を標的とした低分子化合物である. 現在, 先行 しているものは臨床開発段階に入っているが, ここで は，これらのうちいくつか代表的なものについて簡単 に紹介する。

\section{(1) BI2536 (15)}

現在もっとも開発が先行しているものがベーリンガ ーインゲルハイム社によって創製された BI 2536 であ る. $\mathrm{BI} 2536$ は酵素レベルで PLK1 活性を $\mathrm{IC}_{50}=0.8$ nM で阻害する強力な PLK1 阻害薬であり, 63 の他の キナーゼに対して 1000 倍以上の PLK1 選択性を示す. この化合物は細胞に処理することにより顕著な $\mathrm{M}$ 期 停止とアポトーシスを誘導する。これは siRNAなど を用いて示されてきたPLK1 阻害によって誘導される 表現型と一致する。 BI2536 は 2-25 nM の範囲で様々 ながん細胞に対し広く増殖抑制効果を示し, またヌー ドマウスを用いたゼノグラフトモデルに IV 投与する ことにより HCT116 移植大腸がんに対し退縮を伴う 強い抗腫瘍効果を示した. 現在 BI2536 は臨床開発段 階であり今後の結果が期待される $(27)$.

(2) (5- (5,6-Dimethoxy-1H-benzimidazol-1-yl) -3\{[2-(trifluoromethyl) -benzyl]oxy\}thiophene2-carboxamide (28)

この化合物はグラクソスミスクライン社によって創 製された PLK1 の ATP 競合阻害薬であり, 酵素レベ ルで PLK1 活性を $\mathrm{IC}_{50}=2.2 \mathrm{nM}$ で阻害し, CDK やい
くつかのチロシンキナーゼを含む 30 のキナーゼに対 し 100 倍以上の選択性をもつ. BI2536 と同様に化合 物処理により, 細胞は $\mathrm{G} 2 / \mathrm{M}$ 期に停止した後にアポ トーシスが誘導される. 現在この化合物をさらに誘導 化したものが臨床試験段階に入っている(27).

\section{(3) ON01910 (29)}

Onconova Therapeutics 社によって創製されたこの 化合物は上記の 2 化合物とは異なり, ATP 非競合型 のPLK1 の阻害薬として報告された。 ON01910も細 胞に G2/M 期での停止とアポトーシスを誘導するが, この化合物は PDGFRや CDK 等の他のキナーゼも阻 害することが知られており，その作用メカニズムに関 しては不明な部分が多い(27). In vivoにおいては, ヌードマウスへの IV 投与によりとくに重篤な毒性も 無く複数種のゼノグラフトモデルにおいて強い抗腫瘍 効果を示した．現在臨床試験が進行中である (27).

以上のようにいくつかの選択的な PLK 阻害薬が前 臨床モデルで優れた薬効を示し, 臨床試験段階に移行 している．今後これらの化合物の Phase II での結果が 待たれるところである.

\section{3. チェックポイント阻害薬}

抗がん薬処理，または放射線照射などによりDNA に損傷を受けると細胞は細胞周期を停止し，DNA 修 復を行なう。これをチェックポイントと呼ぶ．がん治 療の視点で考えると, チェックポイントは正常組織を 損傷から守るという意味では利点であるが，がん細胞 に対する障害性を減弱させるという点ではむしろデメ リットである. DNA 損傷に伴うチェックポイントに は G1，S， G2 チェックポイントが存在する．多くの がん細胞では p53の変異により G1 チェックポイント が欠損している. 従って p53 非依存のチェックポイン 卜阻害薬が出来れば, がん細胞特異的増強薬となり, がん治療に有益であろう。 S， G2 チェックポイントに 重要な制御因子は Chk1，2で，両者は CDC25をリン 酸化し不活化することによりチェックポイントを活性 化する. 最近 1,2 年でこの pathway を標的とした阻 害薬が開発され，臨床試験が開始されている．以下に そのいくつかを紹介する.

\section{(1) AZD7762}

2007 年にアストラゼネカ社より公表された選択的 な ATP 競合型 Chk（Check）阻害薬 (30)。酵素阻害 活性は, Chk1 = $3.6 \mathrm{nM}, \quad \mathrm{Chk} 2=<10 \mathrm{nM}$ (いずれ も $\left.\mathrm{IC}_{50}\right)$ と非常に強く, これ以外のキナーゼに対し て選択的と報告されている. In vitro 細胞実験で AZD7762 は DNA 損傷による G2 チェックポイントを 
阻害し，ゲムシタビンなどの抗がん薬の $\mathrm{GI}_{50}$, また は $\mathrm{GI}_{100}$ （抗がん薬が細胞増殖をそれぞれ 50\%，100\% 抑制するために必要な濃度）を低下させる。すなわち 抗がん薬の効果を増強する。 ヌードマウス, ヌードラ ットを用いたゼノグラフトモデルに扔いても AZD7762 はゲムシタビン, イリノテカンの抗腫瘍効 果を促進する. PD マーカーは Chk1 のリン酸化, $\gamma \mathrm{H} 2 \mathrm{AX}$ のリン酸化が紹介されており, Chk1 セリン 345 のリン酸化, セリン 296 のリン酸化はゲムシタビ ン処理により増加し,さらにAZD7762により前者は さらに増加, 後者は逆に抑制される. $\gamma \mathrm{H} 2 \mathrm{AX}$ のリン 酸化はゲムシタビン処理により増加し, さらに AZD7762によりさらに増加する. AZD7762 は現在 Phase I 臨床試験に入っており, ゲムシタビンまたは イリノテカンとの併用で治験が進められている. 投与 経路は IV である.

\section{(2) PF-00477736}

ファイザー社が創製したATP 競合型 Chk1， 2 阻害 薬である。酵素阻害活性は, Chk1 = $0.49 \mathrm{nM}, \quad C h k 2$ $=0.047 \mathrm{nM}$ と非常に強く, 一方 CDC2 の阻害活性は $9.9 \mu \mathrm{M}$ と弱い(いずれも Ki). In vitro でゲムシタビン, イリノテカン, カルボプラチンによって誘導されたチ エックポイントを阻害し, in vivo でのヌードマウス を用いたゼノグラフトモデル（Colo-205, HT-29）に 扔いてもゲムシタビン，イリノテカンの抗腫瘍効果を 増強する (31). 現在 Phase I 臨床試験に入っており, ゲムシタビンとの併用で治験が進められている. 投与 経路は IVである。

\section{(3) XL844}

エクセリシス社が創製した ATP 競合型 Chk1，2 阻 害薬で, 酵素阻害活性は Chk1 = $2.2 \mathrm{nM}, \quad \mathrm{Chk} 2=$ $0.07 \mathrm{nM}$ （いずれも Ki）と非常に強い. KDR, Flt3, Flt4, PDGFR $\beta$ に対しても阻害活性を持つが（ IC $_{50}$ は それぞれ $12,28,6,25 \mathrm{nM})$ これら以外のキナーゼ に対して比較的選択的と報告されている. In vitro 細 胞実験によりXL844 はゲムシタビンによる G2 チェッ クポイントを阻害し, premature entry of mitosis を誘 導する。ささに clonogenic assayにより，XL844 はゲ ムシタビンだけでなくシスプラチン, SN38, 放射線 照射の効果を促進する．PD マーカーとしては， M 期 誘導のマーカーである Histone H3 リン酸化の誘導, $\gamma \mathrm{H} 2 \mathrm{AX}$ リン酸化の誘導, G2/M 期に働く Cdc2 のチ ロシン 15 のリン酸化阻害が認められている. In vivo でのヌードマウスを用いたゼノグラフトモデルにおい てもXL844 はゲムシタビンの抗腫瘍効果を増強する (32). XL844 は現在 Phase I 臨床試験に入っており,
ゲムシタビンとの併用で治験が進められている.

\section{(4) CBP501}

CanBas 社が創製した合成ペプチドで，Chk1，2 に よる CDC25C のセリン 216 のリン酸化を阻害する. Chkl，2 の酵素阻害活性はそれぞれ 3.4, $6.5 \mu \mathrm{M}$ で ある. CBP501 はブレオマイシンによるチェックポイ ントで停止した Jurkat 細胞の G2 期量を減少させ, $\mathrm{CDC} 2$ チロシン 15 のリン酸化阻害, Histone H3 リン 酸化の誘導を引き起こす。ささらにCBP501 はシスプラ チン, ブレオマイシンによる細胞障害作用を増強させ る。ヌードマウスを用いたゼノグラフトモデル (HCT116) に拈いても CBP501 はシスプラチン, ブ レオマイシンによる抗腫瘍効果を立進する。この際に これら抗がん薬による体重減少作用は CBP501により ほとんど影響されなかった(33). CBP501の治験は 2005 年より開始されており, シスプラチンとの併用 で進められている。

\section{CDK 阻害薬}

細胞の異常増殖はがん細胞の 1 つの特徵であり, サ イクリン依存性キナーゼ (cyclin-dependent kinase, CDK）は抗がん薬の標的として比較的古くから注目 されている. CDK は哺乳類細胞では少なくとも 13 種 類が知られている。このうち CDK4, CDK6, CDK2, $\mathrm{CDK} 1$ (CDC2), $\mathrm{CDK} 7$ の 5 種類が細胞周期進行に働 いているが，一方で細胞周期制御以外の機能を持つも のも知られている。例えば CDK7 や CDK9 は RNA ポ リメラーゼ II の C 末端ドメイン (C-terminal domain, CTD）をリン酸化することで, 転写伸長反応に関わ ること, CDK5 は神経細胞の機能調節など, 様々な機 能を有することが分かっている。これまで多くの $\mathrm{CDK}$ 阻害薬が報告され, かつ臨床試験入りしている. これらは，1）pan CDK 阻害薬，2）サブタイプ選択 的阻害薬, 3) $\mathrm{CDK}$ 阻害薬で, $\mathrm{CDK}$ 以外のキナーゼ にも阻害活性を持つもの，の 3 つに大別される，1) ではフラボピリドール (Alvocidib) が古くから臨床試 験入りしており, 単薬では慢性リンパ球性白血病 (CLL) で Phase III, 他薬との併用で Phase II 試験が 進行中である. 以下に近年フェーズ入りした化合物に ついて，詳細を紹介したい。

\section{(1) $\mathbf{R 5 4 7}$}

ロシュ社が創製した低分子阻害薬，酵素阻害活性は $\mathrm{CDK} 1=2 \mathrm{nM}, \quad \mathrm{CDK} 2=3 \mathrm{nM}, \quad \mathrm{CDK} 4=1 \mathrm{nM}($ い ずれも Ki), 調べた CDK 以外の 20 キナーゼに対して は 1000 倍以上の選択性を持つ. In vitro では細胞周期 を G1 および G2 期で停止させ, 幅広い細胞種に対し 
て増殖抑制効果を持つ $\left(\mathrm{IC}_{50}=40-1000 \mathrm{nM}\right)$. ヌー ドマウスを用いたゼノグラフトモデルにおいても幅広 いがん種に対して抗腫瘍効果を示す(34). 現在 Phase I 臨床試験が進行中，投与経路は IVである.

\section{(2) AT7519}

Astex 社が創製した低分子阻害薬 (35), 酵素阻害活 性は $\mathrm{CDK} 1=190 \mathrm{nM}, \mathrm{CDK} 2=5 \mathrm{nM}, \mathrm{CDK} 4=67$ $\mathrm{nM}, \mathrm{CDK} 6=660 \mathrm{nM}, \quad \mathrm{CDK} 5=18 \mathrm{nM}, \mathrm{CDK} 7=$ $2800 \mathrm{nM}, \mathrm{CDK} 9=<100 \mathrm{nM}$ (いずれも $\left.\mathrm{IC}_{50}\right)$ ，さら に GSK3 $\beta$ にも阻害活性を持つ $(98 \mathrm{nM})$. In vitro では 幅広い細胞種に対して増殖抑制効果を持ち $\left(\mathrm{IC}_{50}=\right.$ 50-600 nM), ヌードマウスを用いたゼノグラフトモ デル（HCT116）においても抗腫瘍効果を示す. 現在 Phase I 臨床試験が進行中，投与経路はIVである.

\section{(3) PD-0332991}

ファイザー社が創製した CDK4，6 選択的低分子阻 害薬，酵素阻害活性は CDK4 = $11 \mathrm{nM}, \mathrm{CDK} 6=15$ $\mathrm{nM}, \mathrm{CDK1}, 2 ， 5=>10 \mu \mathrm{M}$ である. In vitro で細 胞に処理すると細胞内の $\mathrm{Rb}$ リン酸化を阻害し, 細胞 周期を G1 期で特異的に停止させる. 細胞の増殖抑制 効果を複数の細胞で調べると, その効果は $\mathrm{Rb}$ positive 細胞に特異的で, $\mathrm{Rb}$ negative 細胞での増殖抑制効果 は認められない。ヌードマウスを用いたゼノグラフト モデルで抗腫瘍効果を検討すると，Colo-205，SF295 などの増殖を顕著に抑制した (36)。この化合物は経口 で Phase I 臨床試験中である.

\section{(4) ZK304709}

Schering Pharm 社が創製した CDK，VEGFR 低分 子阻害薬である。酵素阻害活性は CDK1 $=50 \mathrm{nM}$, $\mathrm{CDK} 2=4 \mathrm{nM}, \quad \mathrm{CDK} 4=61 \mathrm{nM}, \quad \mathrm{CDK} 7=85 \mathrm{nM}$, CDK9 $=5 \mathrm{nM}, \quad$ VEGFR1 $=10 \mathrm{nM}, \quad \mathrm{KDR}=34 \mathrm{nM}$, VEGFR3 $=1 \mathrm{nM}, \quad$ PDGFR $\beta=27 \mathrm{nM}$ (いずれも $\mathrm{IC}_{50}$ ) である. In vitro で細胞に処理すると細胞周期 を停止し、アポトーシスを誘導する。 ヌードマウスを 用いたゼノグラフトモデルでも顕著な抗腫瘍効果を示 し，血管新生を阻害する(37)。この化合物は経口で Phase I 臨床試験中である.

\section{文 \\ 献}

1) Hanahan D, et al. Cell. 2000;100:57-70.

2) Marumoto T, et al. Nat Rev Cancer. 2005;5:42-50.

3) Gautschi O, et al. Clin Cancer Res. 2008;14:1639-1648.

4) Harrington EA, et al. Nat Medicine. 2004;10:262-267.

5) Rubin EH, et al. J Clin Oncol. 2006;24 June 20 Suppl:Abstr 3009

6) Giles F, et al. Blood. 2007;109:500-502.

7) Carpinelli P, et al. Mol Cancer Ther. 2007:6:3158-3168.

8) Wilkinson RW, et al. Clin Cancer Res. 2007;13:3682-3688.

9) Schellens JH, et al. J Clin Oncol. 2006;24:122s

10) Manfredi MG, et al. Proc Natl Acad Sci USA. 2007;104:4106-4111.

11) Jones SF, et al. Proc Am Soc Clin Oncol Annu Meet. 2007:25:3577.

12) Sells TB, et al. Proc $99^{\text {th }}$ Annu Meet Am Assoc Cancer Res. 2008; Abstr 237.

13) Barr FA, et al. Nat Rev Mol Cell Biol. 2004;5:429-440.

14) Liu X, et al. Mol Cell Biol. 2006;26:2093-2108.

15) Steegmaier M, et al. Curr Biol. 2007;17:316-322.

16) Lénárt $P$, et al. Curr Biol. 2007;17:304-315.

17) Strebhardt K, et al. Nat Rev Cancer. 2006;6:321-330.

18) Wolf G, et al. Oncogene. 1997;14:543-549.

19) Knecht R, et al. Cancer Res. 1999;59:2794-2797.

20) Strebhardt K, et al. JAMA. 2000;283:479-480.

21) Weichert W, et al. World J Gastroenterol. 2005;11:5644-5650.

22) Smith MR, et al. Biochem Biophys Res Commun. 1997;234: 397-405.

23) Spankuch-Schmitt B, et al. J Natl Cancer Inst. 2002;94:18631877.

24) Spankuch B, et al. J Natl Cancer Inst. 2004;96:862-872.

25) Guan R, et al. Cancer Res. 2005;65:2698-2704.

26) Cogswell JP, et al. Cell Growth Differ. 2000;11:615-623

27) Schmidt M, et al. Drug Resist Updat. 2007;10:162-181.

28) Lansing TJ, et al. Mol Cancer Ther. 2007;6:450-459.

29) Gumireddy K, et al. Cancer Cell. 2005;7:275-286.

30) Ashwell S, et al. AACR Ann Mtg. 2007.

31) Anderes S, et al. Eur J Cancer. 2006;Suppl 4: Abstr 373.

32) Matthews DJ, et al. Cell Cycle. 2007;6:104-110.

33) Sha S, et al. Mol Cancer Ther. 2007:6:147-153.

34) DePino W, et al. Mol Cancer Ther. 2006;5:1644-1658.

35) Squires MS, et al. ASH 49th Ann Mtg. 2007;Abstr 3127

36) Fry DW, et al. Mol Cancer Ther. 2004;3:1427-1438.

37) Siemeister G, et al. Biomed Pharmacother. 2006;60:269-272.

\section{遺伝子略号}

FLT : Fms-related tyrosine kinase 1 (vascular endothelial growth factor receptor 1)

Bcr-Abl : Breakpoint cluster region-Abelson murine leukemia viral oncogene homolog

KDR : Vascular endothelial cell growth factor receptor 2

PDGFR $\beta$ : Platelet-derived growth factor receptor beta chain

GSK3 $\beta$ : Glycogen synthase kinase-3 beta

$\mathrm{Rb}:$ Retinoblastoma 